2. Жадин В.И. Моллюски пресных и солоноватых вод СССР. Москва - Ленинград : изд-во АН СССР. 1952. 376 с.

3. Korniushin A.V., Yanovich L.N., Melnichenko R.K. Artenliste der Süfswassermuscheln der Ukraine. Mit Bemerkungen über taxonomischen Status, Verbreitung und Gefährdungskategorien einiger Arten und Formen. ConchBooks : Friedrich-HeldGesellschaft, 2002. S. 463-478.

4. Стадниченко А. П. Фауна України. Перлівницеві. Кулькові (Unionidae, Cycladidae). К. :Наук. думка, 1984. Т. 29. Вип. 9. 384c.

5. Piechocki A. Dyduch-Falniowska A. Mięczaki (Mollusca), małże (Bivalvia). Fauna słodkowodna Polski, z. 7A. Wydawnictwo Naukowe PWN, Warszawa, 1993. 202 pp.

DOI https://doi.org/10.30525/978-9934-26-111-4-10

\title{
ЕКОЛОГІЧНІ ПРОБЛЕМИ ТИЛІГУЛЬСЬКОГО ЛИМАНУ
}

\author{
Бургаз М. I. \\ кандидат біологічних наук, \\ дочент кафедри водних біоресурсів та аквакультури \\ Одеський державний екологічний університет \\ Шекк П. В. \\ доктор сільськогосподарських наук, професор, \\ завідувач кафедри водних біоресурсів та аквакультури \\ Одеський державний екологічний університет
}

Лічна А. I.

асистент кафедри водних біоресурсів та аквакультури

Одеський державний екологічний університет

м. Одеса, Україна

Тилігульський лиман розташований в 40 км від м. Одеси на кордоні Одеської та Миколаївської областей. Лиман уявляє собою затоплену морськими водами долину річки Тилігул. Лиман відокремлений від моря природним піщано-черепашковим пересипом шириною від 3,3 до 4,0 км і довжиною до 6,6 км. Формування пересипу відбулося наприкінці XVIII - на початку XIX сторіч. Нині пересип $\epsilon$

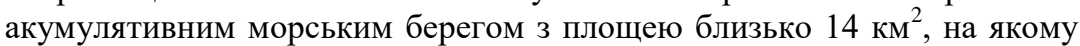
відкладається 70 тис. м $^{3}$ наносів на рік [1]. 
В результаті антропогенної трансформації басейну Тилігульського лиману i кліматичних змін, відсутність науково обгрунтованих планів водного та екологічного менеджменту, природні ресурси Тилігульського лиману сьогодні знаходяться у депресивному стані.

Одна з головних проблем лиману - прогресуюча евтрофікація, яка приводить до «цвітіння» водойми і інтенсивного розвитку макрофітів в літній період. Такі явища в свою чергу сприяють розвитку гіпоксії в придонному шарі глибоких ділянок акваторії лиману, а також на мілководді в нічний час, особливо, при штилі і сильному прогріві вод.

Розвиток дефіциту кисню у воді супроводжується загибелю гідробіонтів. Масова загибель риби (в основному бичків та кефалі) спостерігалася влітку 2010 р. через екстримальні погодні умови сильні зливи у червні липні і аномально високу температуру води в липні - серпні. На окремих ділянках узбережжя спостерігалися вали до 20 кг мертвої риби на квадратний метр.

Це не одиничний приклад масової загибелі гідробіонтів в Тілігульському лимані в результаті задухи. У різних частинах його акваторіях влітку практично щороку (в 1999, 2000, 2001, 2006, 2007; 2012; 2016; 2018 рр.) спостерігалися локальні явища загибелі риб і безхребетних.

У 2014 р. метеорологічні та гідрологічні умови (різке похолодання при тривалому штормовому вітрі, інтенсивна конвекція водних мас при негативних значеннях температури і значної солоності) привели до загибелі статевозрілих особин піленгасу при становленні льоду на Тилігульському лимані [1].

Друга серйозна проблема - поступове підвищення солоності вод (засолення) лиману в результаті зменшення притоку прісних вод 3 водозбору і надходження морських вод в лиман при інтенсивному випаровуванні в літній період року. За відсутності водообміну з морем, до кінця літа на початку осені солоність води як у південній, так і в північній частинах лиману може зростати до 25-30\%о і більше. Підвищення солоності вод призводить до зміни домінуючого солонуватоводного комплексу риб на морський, для якого властива значно менша видова різноманітність.

Найбільш негативні наслідки для екосистеми лиману спричиняє критичне зменшення поверхневого стоку (річок Тилігул, Балайчук, Царега та схилового стоку по балках, ярах), викликане як антропогенною діяльністю (створенням каскаду штучних водойм, перетворенням природних ландшафтів, розорювання земель, вирубкою 
лісопосадок та знищенням переважної частини природного рослинного покриву), так і кліматичними змінами.

Так наприклад, за оцінками Н. С. Лободи [2] в результаті кліматичних змін норма природного (не порушеного господарською діяльністю) річного стоку з водозбору р. Тилігул в Тилігульський лиман, в порівнянні з серединою минулого століття, зменшилася на 30\%. Крім того, на водозборі річки ведеться активна водогосподарська діяльність. Згідно з даними Каталогів водного фонду Одеської та Миколаївської областей загальна кількість штучних водойм, розташованих в басейні Тилігульського лиману складає 157 одиниць а їхній загальний об'єм перевищує 19 млн. м ${ }^{3}$.

Вилучення стоку річки Тилігул на наповнення понад сотні водойм розташованих на іiі водозборі, 3 подальшим випаровуванням 3 їх поверхні, призводить до сумарного зменшення природного стоку цієї річки на 54\% [2]. Зменшення водності р. Тілігул призвело до всихання протягом другої половини минулого століття близько 40\% плавнів на ділянці їі впадіння в північну частину лиману. Оскільки в літні місяці випаровування 3 поверхні лиману в 3 рази перевищує атмосферні опади, то зменшення припливу прісних вод в лиман призводить до осолонення і обміління лиману, збільшення концентрації біогенних речовин i темпів продукування органічної речовини фітоплактоном $\mathrm{i}$ донними макрофітами в мілководних зонах. Подальше відмирання i біохімічний розпад органічної речовини водоростей сприяє розвитку дефіциту вмісту кисню у воді, загибелі гідробіонтів, збідніння біорізноманіття водної флори і фауни. Складаються несприятливі умови для рибальства, рекреації та туризму.

Негативний вплив на екосистему Тилігульського лиману спричиняє також сільськогосподарська діяльність на його водозборі i, особливо, на берегових схилах. Розорювання земель та випас худоби в прибережній захисній смузі, використання добрив, пестицидів у рослинництві та садівництві призводять до забруднення вод лиману, додатковому надходженню в лиман в період весняної повені та інтенсивних літніх злив зважених наносів і гумусу, біогенних речовин в мінеральній і органічній формі, зменшенню прозорості та збільшенню температури води поверхневого шару, загострення сезонного пікноклину, розвитку евтрофікації з усіма негативними їі наслідками.

Додаткове антропогенне навантаження на екосистему лиману спричиняє господарсько-побутова діяльність населення, чисельність якого на узбережжі Тилігульського лиману і прилеглих територіях істотно зросла за останні десятиліття в результаті інтенсивного дачного 
освоєння прилеглих до лиману територій (16 тис. дачних садовогородніх ділянок тільки на західному узбережжі лиману між селами Кашари і Мар'янівка).

До числа негативних наслідків цієї діяльності слід віднести порушення природних ландшафтів, місць проживання та гніздування птахів, знищення унікальної флори і фауни, утворення сміттєзвалищ через відсутність системи утилізації сміття, побутових відходів, скидання неочищених стічних вод в лиман, які потрапляють в нього 3 водотоками за відсутності каналізації, змив в лиман в період весняної повені та літніх злив добрив, пестицидів, які використовуються в дачних господарствах. Скидання неочищених стічних вод у поверхневі водні об'єкти басейну Тилігульського лиману складає за експертними оцінками 350-400 тис. м $^{3} \cdot$ рік $^{-1}$.

Водообмін лиману 3 морем через з'єднувальний штучний канал також має як позитивні, так і негативні сторони. Позитивний вплив полягає в тому, що функціонування каналу запобігає значне падіння рівня води в лимані до кінця літнього періоду, запобігає обмілінню мілководних ділянок лиману (північної частини, підводних перемичок в районі кіс, які поділяють лиман на частини), сприяє оновленню забруднених вод лиману відносно чистими морськими, забезпечує інтенсифікацію водообміну між глибокими частинами лиману, розділеними мілководними перемичками. Функціонування каналу у весняний період дає можливість заходити в лиман на нагул молоді морських риб, що сприяє збільшенню його рибних ресурсів і розвитку промислового і любительського рибальства. При низькому рівні води в лимані, в результаті осушення і зникнення прибережних мілководь, зменшується площа кормових ділянок для деяких охоронюваних видів птахів, зростає доступність гніздівель для наземних хижаків [4].

Негативний вплив каналу полягає в тому, що при високому рівні моря відбувається підтоплення традиційних місць гніздування птахів, активізуються абразійно-зсувні процеси на берегах лиману, зростає ймовірність інтрузії морських вод у заплаву р.Тилігул - водно-болотні угіддя. Нерегульований водообмін з морем через з'єднувальний канал, при практично повній відсутності прісноводного стоку, сприяє накопиченню солей в лимані і підтримує багаторічну тенденцію до збільшення солоності його вод. Це може призвести до перетворення лиману в гіпергалинну водойму зі значно меншим біорізноманіттям водної флори і фауни.

Екологічний стан та рибопродуктивність Тилігульського лиману тісно пов'язані з гідролого-гідрохімічним режимом водойми, який 
приділяється іiі зв'язком з морем, обсягом прісноводного материкового стоку, об'ємом опадів, та випарюванням з поверхні. В роки, коли водний баланс позитивний, іхтіофауна водойми відрізняється різноманітністю, а рибопродуктивність зростає.

В цей час завершено будівництво стаціонарного каналу, який з'єднав Тилігульський лиман і Чорне море і в наступні роки забезпечить постійний водообмін цими акваторіями i зариблення лиману морською іхтіофауною.

\section{Література:}

1. Перспективи рибогосподарського використання лиманів північно-західного Причорномор'я: монографія / за ред. П. В. Шекка, М. І. Бургаз; М. Г. Сербов, О. А. Тучковенко, Т. І. Матвієнко, О. М. Соборова, К. І. Безик, А. І. Лічна : монографія. Одеса: 2021. 217 с.

2. Лобода Н.С. Оценка притока пресных вод в Тилигульский лиман. Актуальные проблемы лиманов северо-западного Причерноморья. Одесса: Одесский гос. эколог. ун-т, 2012. С. 140-148.

3. С. М. Снигирев., С. Г. Бушуев., А. П. Куракин, Гибель пиленгаса LIZA HAEMATOCHEILUS (TEMMINCK \& SCHLEGEL, 1845) в Тилигульском лимане. Вісник ОНУ. Сер.: Біологія., 2014. Т. 19. В. 1(34). С. $90-101$

4. Стойловский В.П. Численность и распределение гнездящихся околоводных птиц в Тилигульском лимане. Причорноморський екологічний бюлетень. Одеса: Одеський центр НТЕI. № 2 2004.- C. 85-96. 